\title{
Analisis SWOT Pada Bank Pembangunan Daerah Sumatera Barat Cabang Simpang Empat
}

\author{
Lidya Martha \\ "Dosen pada STIE"KBP" Padang"
}

\begin{abstract}
This research aims to know the right strategies, powerful competitiveness which can be done by SimpangEmpat Branch Office of Bank Pembangunan Daerah with first identify environmental factors in terms of internal and external SimpangEmpat Branch Office of Bank Pembangunan Daerah that could affect the company's. The analysis tool is a method of SWOT analysis (Strenght, Weakness, Oppurtunity, Threat). The results showed that the strategy must be carried out by SimpangEmpat Branch Office of Bank Pembangunan Daerah is a vigorous marketing strategy and should be done by SimpangEmpat Branch Office of Bank Pembangunan Daerah was with increased promotional products to all walks of life, expand your network and improvement of operational and technology, as well as improving the quality of human resources management and service.

Keyword: SWOT, bank, strategy
\end{abstract}

\section{PENDAHULUAN}

\section{Latar Belakang}

Perkembangan bisnis di Indonesia belakangan ini semakin lama semakin meningkat akan kompleksitas, persaingan, perubahan, dan ketidakpastian. Keadaan ini menimbulkan persaingan yang tajam antara perusahaan, baik karena pesaing yang semakin bertambah, volume produk yang semakin meningkat, maupun bertambah pesatnya perkembangan teknologi. Hal ini memaksa perusahaan untuk lebih memperhatikan lingkungan yang dapat mempengaruhi perusahaan, agar perusahaan mengetahui strategi seperti apa dan bagaimana yang harus diterapkan dalam perusahaan (Prawitasari, 2010).

Perusahaan perlu mengenali kekuatan dan kelemahan perusahaan dalam persaingan. Hal ini akan sangat membantu perusahaan dalam mengenali diri, serta memanfaatkan setiap peluang yang ada dan menghindari atau meminimalkan ancaman. Pernyataan ini juga diungkapkan oleh Guiltinan (Prawitasari, 2010), dimana dalam menentukan strategi bersaing dan mengambil keputusan, seorang manajer harus mengenali apa saja kelemahan, kekuatan, ancaman, peluang yang dimiliki perusahaan serta mengenali keunggulan pesaing yang mungkin dimiliki.

Industri perbankan pada saat ini dihadapkan pada persaingan yang sangat tajam dan juga kompleks yang dikarenakan perubahan lingkungan bisnis yang cepat. Penyebab terjadinya persaingan yang tajam ini adalah banyaknya bank-bank yang berdiri dan menawarkan jasa-jasa perbankan yang inovatif. Begitu juga dengan lembaga keuangan non bank yang juga telah banyak beroperasi. Hal ini sama halnya dengan yang dinyatakan oleh Lovelock (Endang, 2007) bahwa sektor jasa merupakan sektor yang paling mengalami perubahan akibat dari cepatnya 
perubahan yang dialami oleh faktor lain, seperti perubahan teknologi yang secara langsung menaikkan iklim kompetisi dalam industri.

Hal ini juga terjadi pada Bank Pembangunan Daerah Sumatera Barat Cabang Simpang Empat. Bank Pembangunan DaerahCabang Simpang Empat didirikan pada tanggal 31 Agustus 1982 dengan tujuan untuk melayani nasabah dalam jasa perbankkan khususnya nasabah yang berdomisili di Kabupaten Pasaman Barat . Visi Bank Pembangunan Daerahcabang Simpang Empat adalah menjadi kantor cabang yang tumbuh secara wajar dan sehat serta mendominasi penguasaan pangsa pasar baik dalam penyaluran kredit maupun penghimpun dana.

Bank Pembangunan Daerah Sumatera Barat Cabang Simpang Empat ini merupakan salah satu bank yang dimiliki oleh pemerintah Sumatera Barat yang diharapkan dapat menjadi salah satu penerimaan untuk pendapatan daerah. Selain itu Bank Pembangunan Daerah Sumatera Barat Cabang Simpang Empat ini juga diharapkan dapat memberikan dukungan bagi pertumbuhan ekonomi di Sumatera Barat, khususnya di Kabupaten Pasaman Barat. Bank ini harus selalu berusaha untuk memenuhi tuntutan tersebut meskipun menghadapi persaingan yang sangat ketat dan tajam diantara lembaga-lembaga keuangan bank dan lembaga-lembaga keuangan non bank yang menjadi pesaingnya di Pasaman Barat.

\section{Perumusan Masalah}

1. Apa saja kekuatan serta kelemahan yang dimiliki olehBank Pembangunan Daerah Sumatera BaratCabang Simpang Empat?

2. Apa saja peluang dan ancaman yang sedang dan yangakan dihadapi olehBank Pembangunan DaerahSumatera BaratCabang Simpang Empat?

3. Strategi apa yang harus diterapkan oleh Bank Pembangunan DaerahSumatera BaratCabang Simpang Empatuntuk mengatasi kelemahan dan ancaman yang dimiliki agar tetap bisa bersaing dengan kompetitor lainnya?

\section{Tujuan Penelitian}

1. Untuk mengetahui kekuatan serta kelemahan yang dimiliki oleh Bank Pembangunan DaerahSumatera BaratCabang Simpang Empat.

2. Untuk mengetahui peluang dan ancaman yang ada pada Bank Pembangunan DaerahSumatera BaratCabang Simpang Empat.

3. Untuk mengetahui strategi apa yang harus diterapkan oleh Bank Pembangunan Daerah Sumatera BaratCabang Simpang Empat untuk mengatasi kelemahan dan ancaman yang dimiliki agar tetap bisa bersaing dengan kompetitor lainnya.

\section{TINJAUAN LITERATUR}

\section{Pengertian Bank}

Bank menurut Undang-undang RI nomor 10 tahun 1998 tanggal 10 November 1998 tentang perbankan dalam bukuKasmir (2008) adalah badan usaha yang menghimpun dana dari masyarakat dalam bentuk simpanan dan menyalurkannya kepada masyarakat dalam bentuk kredit dan atau bentuk-bentuk lainnya dalam rangka meningkatkan taraf hidup rakyat banyak.

Pengertian menghimpun dana maksudnya adalah mengumpulkan atau mencari dana (uang) dengan cara membeli dari masyarakat luas dalam bentuk simpanan giro, tabungan dan deposito. Pembelian dana dari masyarakat ini dilakukan oleh bank dengan cara memasang berbagai strategi agar masyarakat mau menanamkan dananya (Septriana 2011 ). Kegiatan menghimpun dana ini sering disebut dengan istilah funding. Strategi bank dalam menghimpun 
dana adalah dengan memberikan rangsangan berupa balas jasa yang menarik dan menguntungkan. Balas jasa tersebut berupa bunga simpanan, kemudian rangsangan lain dapat berupa cendera mata, hadiah, pelayanan yang menyenangkan hati, atau balas jasa lainnya. Semakin beragam dan menguntungkan balas jasa yang diberikan, akan menambah minat masyarakat untuk menggunakan produk bank tersebut. Oleh karena itu pihak perbankan harus memberikan berbagai rangsangan dan kepercayaan sehingga masyarakat berminat untuk menanamkan dananya di bank (Kasmir, 2010).

\section{Pemasaran}

Sangat banyak sekali pendapat para ahli ekonomi dunia tentang pengertian pemasaran ini diantaranya yaitu:

1. MenurutThe American Marketing Association (AMA).

Pemasaran merupakan organisasional dan penciptaan satu set proses-proses, komunikasi dan mengirimkan nilai pada konsumen-konsumen, dan untuk mengatur relasi pada konsumen yang bertujuan untuk keuntungan pihak-pihak yang bersangkutan.

2. Menurut Freddy Rangkuti (2005).

Pemasaran adalah suatu proses kegiatan yang dipengaruhi oleh berbagai faktor sosial, budaya, politik, ekonomi dan manajerial.

3. Menurut Philip Kotler(2000).

Pemasaran secara sederhana adalah yang mengatur relasi menguntungkan dengan konsumen. Tujuan dari pemasaran adalah menciptakan nilai untuk konsumen dan untuk menangkap nilai dari konsumen atau mendapat timbal balik dari konsumen.

\section{Lingkungan Pemasaran}

Lingkungan Pemasaran adalah lingkungan perusahaan yang terdiri dari pelaku dan kekuatan di luar pemasaran yang mempengaruhi kemampuan manajemen pemasaran untuk membangun dan mempertahankan hubungan yang berhasil dengan pelanggan sasaran. Lingkungan pemasaran merupakan komponen kekuatan-kekuatan diluar aspek pemasaran yang dapat mempengaruhi kemampuan manajemen dalam membangun dan memelihara hubungan dengan pelanggan yang terdiri dari lingkungan internal (mikro) dan lingkungan eksternal (makro)

Sebagai salah satu pelaku dalam lingkungan mikro, perusahaan mengelola kegiatan pokok meliputi produksi, keuangan, sumber daya manusia, pemasaran, serta riset dan pengembangan. Kelima kegiatan pokok perusahaan ini merupakan lingkungan internal perusahaan (Kotler, 2000). Sedangkan pemasok, perantara, konsumen dan pesaing berada di luar perusahaan merupakan lingkungan eksternal perusahaan.

\section{Strategi Pemasaran}

Secara khusus strategi diartikan sebagai taktik atau siasat. David, Fred R (2004) mengatakan strategi adalah cara untuk mencapai tujuan jangka panjang dan merupakan tindakan yang menuntut keputusan manajemen puncak dan sumber daya perusahaan yang banyak untuk merealisasikannya.

Strategi Pemasaran didasarkan kepada analisis manajer perusahaan akan lingkungan perusahaan baik internal maupun eksternal. Terdapat tiga elemen pokok menurut Tjiptono (Prawitasari, 2010) dalam strategi pemasaran : 


\section{Konsumen}

Pemasaran berawal dari kebutuhan dan keinginan pelanggan serta berakhir dengan kepuasan dan loyalitas pelanggan. Pemasar wajib memahami siapa saja pelanggannya, preferensi, karakteristik, kebutuhan, keinginan, gaya hidup, serta faktor-faktor yang berpengaruh terhadap pola konsumsi mereka.

\section{Pesaing}

Memenuhi kepuasan konsumen belumlah cukup. Apabila ada pesaing yang sanggup memuaskan pelanggan dengan lebih baik, maka pelanggan akan beralih ke pesaing. Oleh sebab itu, setiap organisasi harus memperhatikan faktor persaingan pula. Faktor tersebut meliputi siapa saja pesaing perusahaan, strategi, kelemahan, kompetensi diri, serta relasi mereka.

\section{Perusahaan}

Tujuan perusahaan dicapai melalui upaya memuaskan pelanggan. Untuk itu dibutuhkan strategi, kinerja, kompetensi diri, sumberdaya (manusia, alam, finansial, teknologi, intelektual, informasi, dan waktu).

\section{Strategi STP (Segmentation, Targeting, Positioning)}

\section{Segmentation}

Segmentasi (Segmentation) menurut Solomon dan Elnora (2003:221), adalah "'The process of dividing a larger market into smaller pieces based on one or more meaningful, shared characteristic". Menurut Solomon dan Elnora (2003:221) ada beberapa variabel segmentasi diantaranya yaitu:

a. Demografis

Segmentasi ini dilakukan dengan membagi pasar ke dalam kelompok-kelompok berdasarkan variabel demografis sepert: usia, jenis kelamin, besarnya keluarga, pendapatan, ras, pendidikan, pekerjaan, geografis.

\section{b. Psikografis}

Segmentasi ini dilakukan dengan membagi pasar ke dalam kelompok-kelompok yang berlainan menurut kelas sosial, gaya hidup, kepribadian, dan lain-lain. Informasi demografis sangat berguna, tetapi tidak selalu menyediakan informasi yang cukup untuk membagi konsumen ke dalam segmen-segmen, sehingga diperlukan segmen berdasarkan psychografis untuk lebih memahami karakteristik konsumen.

c. Perilaku

Segmentasi ini dilakukan dengan membagi konsumen ke dalam segmen-segmen berdasarkan bagaimana tingkah laku, perasaan, dan cara konsumen menggunakan barang/situasi pemakaian, dan loyalitas merek. Cara untuk membuat segmen ini yaitu dengan membagi pasar ke dalam pengguna dan non-pengguna produk.

\section{Targeting}

Menurut Solomon dan Elnora (2003:232), Target market ialah "Group that a firm selects to turn into customers as a result of segmentation and targeting". Setelah pasar dibagibagi dalam segmen-segmen, maka perusahaan harus memutuskan suatu strategi target market. 
Menurut Solomon dan Elnora (2003:232) perusahaan dapat memilih dari empat strategi peliputan pasar:

\section{a. Undifferentiated targeting strategy}

Strategi ini menganggap suatu pasar sebagai satu pasar besar dengan kebutuhan yang serupa, sehingga hanya ada satu bauran pemasaran yang digunakan untuk melayani semua pasar. Perusahaan mengandalkan produksi, distribusi, dan periklanan massa guna menciptakan citra superior di mata sebagian besar konsumen.

\section{b. Differentiated targeting strategy}

Perusahaan menghasilkan beberapa produk yang memiliki karakteritik yang berbeda. Konsumen membutuhkan variasi dan perubahan sehingga perusahaan berusaha untuk menawarkan berbagai macam produk yang bisa memenuhi variasi kebutuhan tersebut.

\section{c. Concentrated targeting strategy}

Perusahaan lebih memfokuskan menawarkan beberapa produk pada satu segmen yang dianggap paling potensial.

\section{d. Custom targeting strategy}

Lebih mengarah kepada pendekatan terhadap konsumen secara individual.

Langkah dalam mengembangkan targeting yaitu:

1). Mengevaluasi daya tarik masing-masing segmen dengan menggunakan variable-variabel yang dapat mengkuantifikasi kemungkinan permintaan dari setiap segmen, biaya melayani setiap segmen, dan kesesuaian antara kompetensi inti perusahaan dan peluang pasar sasaran.

2). Memilih satu atau lebih segmen sasaran yang ingin dilayani berdasarkan potensi laba segmen tersebut dan kesesuaiannya dengan strategi korporat perusahaan.

\section{Positioning}

Menurut Solomon, dan Elnora (2003:235), Positioning ialah “Developing a marketing strategy aimed at influencing how a particular market segment perceives a good or service in comparison to the competition". Penentuan posisi pasar menunjukkan bagaimana suatu produk dapat dibedakan dari para pesaingnya. Menurut Solomon dan Elnora (2003:235) ada beberapa positioning yang dapat dilakukan yaitu:

1). Positioning berdasarkan perbedaan produk.Pendekatan ini dapat dilakukan jika produk suatu perusahaan mempunyai kekuatan yang lebih dibandingkan dengan pesaing dan konsumen harus merasakan benar adanya perbedaan dan manfaatnya.

2). Positioning berdasarkan atribut produk atau keuntungan dari produk tersebut.Pendekatan ini berusaha mengidentifikasikanatribut apa yang dimiliki suatu produk dan manfaat yang dirasakan oleh kosumen atas produk tersebut.

3). Positioning berdasarkan pengguna produk.Pendekatan ini hampir sama dengan targeting dimana lebih menekankan pada siapa pengguna produk.

4). Positioning berdasarkan pemakaian produk.Pendekatan ini digunakan denganmembedakan pada saat apa produk tersebutdikonsumsi.

5). Positioning berdasarkan pesaing.Pendekatan ini digunakan dengan membandingkan keunggulan-keunggulan yang dimiliki oleh pesaing sehingga konsumen dapat memilih produk mana yang lebih baik. 
6). Positioning berdasarkan kategori produk.Pendekatan ini digunakan untuk bersaing secara langsung dalam kategori produk, terutama ditujukan untuk pemecahan masalah yang sering dihadapi oleh pelanggan.

7). Positioning berdasarkan asosiasi.Pendekatan ini mengasosiasikan produk yang dihasilkan dengan asosiasi yang dimiliki oleh produk lain. Harapannya adalah sebagian asosiasi tersebut dapat memberikan kesan positif terhadap produk yang dihasilkan oleh perusahaan.

8). Positioning berdasarkan masalah.Pendekatan ini digunakan untuk menunjukkan kepada konsumen bahwa produk yang ditawarkan memiliki positioning untuk dapat memecahkan masalah.

\section{Analisis SWOT}

Analisis SWOT (Strength, Weakness, Opportunity and Threat) adalah metode perencanaan strategis yang digunakan untuk mengevaluasi kekuatan, kelemahan, peluang, dan ancaman dalam suatu proyek atau suatu spekulasi bisnis. Proses ini melibatkan penentuan tujuan yang spesifik dari spekulasi bisnis atau proyek dan mengidentifikasi faktor internal dan eksternal yang mendukung dan yang tidak dalam mencapai tujuan tersebut.

Teori Analisis SWOT adalah sebuah teori yang digunakan untuk merencanakan sesuatu hal yang dilakukan dengan SWOT. SWOT ini biasa digunakan untuk menganalisis suatu kondisi dimana akan dibuat sebuah rencana untuk melakukan sesuatu, sebagai contoh, program kerja. Teknik ini dibuat oleh Albert Humphrey, yang memimpin proyek riset pada Universitas Stanford padadasawarsa 1960-an dan 1970-an dengan menggunakan data dari perusahaanperusahaan Fortune 500.

Gambar 1

Diagram analisis SWOT

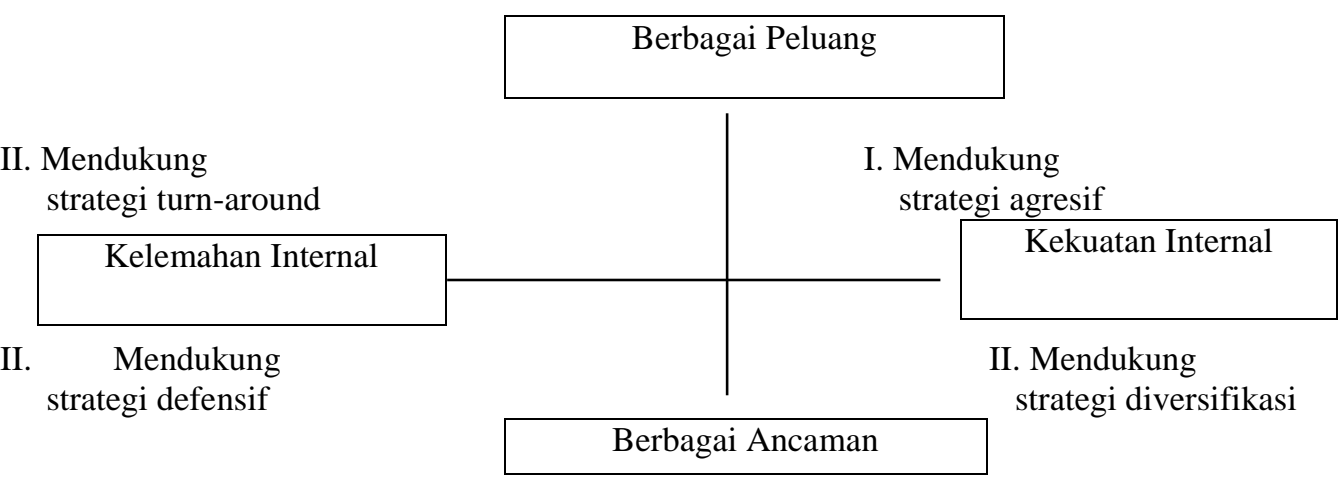

Sumber : Freddy Rangkuti (2005)

Kuadran I, ini merupakan situasi yang sangat menguntungkan. Perusahaan tersebut memiliki peluang dan kekuatan sehingga dapat memanfaatkan peluang yang ada. Strategi yang harus diterapkan dalam kondisi ini adalah mendukung kebijakan pertumbuhan yang agresif ( Growth oriented strategy).

Kuadran II, meskipun menghadapi berbagai ancaman, perusahaan ini masih memiliki kekuatan dari segi internal. Strategi yang harus diterapkan adalah menggunakan kekuatan 
untuk memanfaatkan peluang jangka panjang dengan cara strategi diversifikasi (produk atau pasar)

Kuadran III, perusahaan menghadapi peluang pasar yang sangat besar, tetapi dilain pihak, ia menghadapi beberapa kendala/kelemahan internal. Fokus strategi perusahaan ini adalah meminimalkan masalah-masalah internal perusahaan sehingga dapat merebut peluang pasar yang lebih baik.

Kuadran IV, ini merupakan situasi yang sangat tidak menguntungkan, perusahaan tersebut menghadapi berbagai ancaman dan kelemahan internal.

\section{SWOT Matrix}

SWOT Matrix menggambarkan berbagai alternatif strategi yang dapat dilakukan oleh perusahaan yang disarankan pada hasil analisis SWOT (strength, weakness, opportunity and threath). Karenanya tidaklah mengherankan jika kemudian ada 4 alternatif strategi yang tersedia untuk dipilih salah satunya atau juga semuanya, strategi tersebut yaitu strategi SO, strategi WO, strategi ST dan strategi WT.

Strategi SO dalam SWOT Matrix ini adalah strategi yang digunakan perusahaan dengan memanfaatkan atau mengoptimalkan kekuatan yang dimilikinya/Strength (S) untuk memanfaatkan berbagai peluang/Opportunities $(\mathrm{O})$ yang ada. Sedangkan WO strategi adalah strategi yang digunakan perusahaan dengan seoptimal mungkin meminimalisir kelemahan/Weakness (W) yang ada untuk memanfaatkan berbagai peluang/Opportunity (O). Strategi ST adalah strategi yang digunakan perusahaan dengan memanfaatkan atau mengoptimalkan kekuatan/Strength (S) untuk mengurangi berbagai ancaman/Threats (T) yang mungkin melingkupi perusahaan. Dan yang terakhir, strategi WT adalah strategi yang digunakan untuk mengurangi kelemahan/Weaknesses (W) dalam rangka meminimalisir atau menghindari ancaman/Threats $(\mathrm{T})$.

\section{METODE PENELITIAN}

Objek Penelitian

Penelitian ini dilakukan di wilayah Simpang Empat, Pasaman Barat dengan objek penelitian adalah Bank Pembangunan Daerah Sumatera Barat Cabang Simpang Empat.

\section{Jenis Penelitian}

Metode analisis deskriptif kualitatif merupakan cara mengidentifikasi dan menganalisis data yang ada sehingga memberikan gambaran yang jelas mengenai kekuatan, kelemahan, peluang, dan ancaman yang dimiliki oleh Bank Pembangunan Daerah Sumatera Barat Cabang Simpang Empat dalam menentukan posisi persaingan yang berguna untuk mengetahui strategi perusahaan didalam dunia bisnis perbankan.

\section{Populasi dan Sampel}

Menurut Augusty T.Ferdinand (Prawitasari, 2010) populasi adalah gabungan dari seluruh elemen yang berbentuk peristiwa, hal atau orang yang memiliki karakteristik yang serupa yang menjadi pusat perhatian seorang peneliti karena dipandang sebagai sebuah semesta penelitian. Yang menjadi populasi dalam penelitian ini adalah semua karyawan Bank Pembangunan Daerah Sumatera Barat Cabang Simpang Empat yang kurang lebih 69 orang 
sudah termasuk untuk karyawan Kantor Kas di Kantor Bupati dan Kantor Kas Simpang Tiga Opir serta Cabang Pembantu di Kinali.

Karena jumlah populasi pada Bank Pembangunan Daerah Sumatera Barat Cabang Simpang Empat adalah kecil dari 100 maka peneliti menjadikan 69 orang tersebut sebagai sampel dari penelitian ini.

\section{Metode Analisis Data}

\section{a. Matriks Strengths Weaknesses Opportunities Threats (SWOT)}

Menurut Rangkuti (2009), analisis SWOT adalah identifikasi berbagai faktor secara sistematis untuk merumuskan strategi perusahaan. Analisis ini didasarkan pada logika yang dapat memaksimalkan strengths (kekuatan) dan opportunities (peluang), namun secara bersamaan dapat meminimalkan weaknesses (kelemahan) dan threats (ancaman). Menurut Umar (2003), matriks strength, weakness, opportunity and threath (SWOT) merupakan matching tool yang penting untuk membantu para manajer mengembangkan empat tipe strategi. Keempat tipe strategi yang dimaksud yaitu:

1. Strategi SO (Strengths - Opportunities)

2. Strategi WO (Weaknesses - Opportunities)

3. Strategi ST (Strengths - Threats)

4. Strategi WT (Weaknesses - Threats)

\begin{tabular}{|l|l|l|}
\hline \multicolumn{1}{|c|}{ Internal Faktor } & $\begin{array}{l}\text { Strengths }-\boldsymbol{S} \\
\text { Catatlah kekuatan-kekuatan } \\
\text { internal perusahaan }\end{array}$ & $\begin{array}{l}\text { Weaknesses }-\boldsymbol{W} \\
\text { Catatlah } \\
\text { kelemahan } \\
\text { perusahaan }\end{array}$ \\
\hline $\begin{array}{l}\text { Opportunities }-\boldsymbol{O} \\
\text { Catatlah peluang-peluang } \\
\text { eksternal perusahaan }\end{array}$ & $\begin{array}{l}\text { Strategi SO } \\
\text { Daftar kekuatan untuk mernal } \\
\text { keuntungan dari peluang } \\
\text { yang ada }\end{array}$ & $\begin{array}{l}\text { Strategi WO } \\
\text { Daftar untuk memperkecil } \\
\text { kelemahan dengan } \\
\text { memanfaatkan keuntungan } \\
\text { dari peluang yang ada }\end{array}$ \\
\hline $\begin{array}{l}\text { Threats - } \boldsymbol{T} \text { Catatlah ancaman-ancaman } \\
\text { eksternal perusahaan }\end{array}$ & $\begin{array}{l}\text { Strategi ST } \\
\text { Daftar kekuatan untuk } \\
\text { menghindari ancaman }\end{array}$ & $\begin{array}{l}\text { Strategi WT } \\
\text { Daftar untuk memperkecil } \\
\text { kelemahan dan menghindari } \\
\text { ancaman }\end{array}$ \\
\hline
\end{tabular}

Matriks SWOT

\section{Strategi SO (Strengths - Opportunities)}

Strategi ini menggunakan kekuatan internal perusahaan untuk meraih peluang-peluang yang ada di luar perusahaan. Pada umumnya, perusahaan berusaha melaksanakan strategistrategi WO, ST, atau WT untuk menerapkan strategi SO. Oleh karena itu, jika perusahaan memiliki banyak kelemahan, mau tidak mau perusahaan harus mengatasi kelemahan itu agar menjadi kuat. Sedangkan, jika perusahaan menghadapi banyak ancaman, perusahaan harus berusaha menghindarinya dan berusaha berkonsentrasi pada peluang-peluang yang ada.

\section{Strategi WO (Weaknesses - Opportunities)}

Strategi ini bertujuan untuk memperkecil kelemahan-kelemahan internal perusahaan dengan memanfaatkan peluang-peluang eksternal. Terkadang perusahaan menghadapi kesulitan untuk memanfaatkan peluang-peluang karena adanya kelemahan-kelemahan internal. 


\section{Strategi ST (Strengths - Threats)}

Melalui strategi ini perusahaan berusaha untuk menghindari atau mengurangi dampak dari ancaman-ancaman eksternal. Hal ini bukan berarti bahwa perusahaan yang tangguh harus selalu mendapatkan ancaman.

\section{Strategi WT (Weaknesses - Threats)}

Strategi ini merupakan taktik untuk bertahan dengan cara mengurangi kelemahan internal serta menghindari ancaman. Suatu perusahaan yang dihadapkan pada sejumlah kelemahan internal dan ancaman eksternal sesungguhnya berada dalam posisi berbahaya. Perusahaan harus terus berjuang untuk tetap dapat bertahan dengan melakukan strategi-strategi seperti merger, declared bankrupitcy, retrench, atau liquidation.

\section{ANALISIS DAN PEMBAHASAN}

Dari penelitian yang telah dilakukan maka telah diperoleh faktor-faktor yang menjadi kekuatan, kelemahan, peluang dan ancaman yang sedang dialami oleh Bank Pembangunan Daerah Sumatera Barat Cabang Simpang Empat. Faktor-faktor tersebut diperoleh melalui kuesioner yang sudah disebar kepada seluruh karyawan Bank Pembangunan Daerah Sumatera Barat Cabang Simpang Empat dan juga melalui observasi atau pengamatan langsung terhadap kondisi lingkungan internal dan eksternal dari Bank Pembangunan Daerah Sumatera Barat Cabang Simpang Empat tersebut.

Berkut ini adalah kondisi lingkungan Bank Pembangunan Daerah Sumatera Barat Cabang Simpang Empat saat ini :

1. Lingkungan Internal

a. Kekuatan

1) Aset keuangan sudah dikelola dengan baik dan benar.

2) SDM yang dimiliki lebih unggul dari pesaing.

3) Mendapat dukungan dan perhatian khusus dari pemerintah Sumatera Barat.

4) Sarana dan prasana yang tersedia relatif lebih mudah dari pesaing.

5) Memiliki SDM yang berusia muda dan potensial untuk dikembangkan.

6) Kerja sama yang baik antar personil.

7) Image Bank Pembangunan Daerah Sumatera Barat (Bank Nagari) dimata masyarakat luas sangat baik.

8) Produk atau jasa yang di tawarkan Bank Pembangunan Daerah Sumatera Barat bervariasi dan diminati oleh masyarakat.

9) Undian hadiah yang dilakukan Bank Pembangunan Daerah Sumatera Barat merupakan apresiasi terhadap pelanggan.

10) Akses atas regulasi dan informasi yang besar

11) Tabungan Sikoci merupakan produk yang paling diminati oleh masyarakat.

12) Jaringan kantorcabang Bank Pembangunan Daerah Sumatera Barat Cabang Simpang Empat cukup potensial dalam penyaluran kredit.

13) Telah memiliki standar dan prosedur dalam pemberian KUR.

b. Kelemahan

1) Masih ada bagian pekerjaan yang kekurangan personil.

2) Beberapa pesaing lebih unggul dalam bidang pemasaran dan teknolgi.

3) Ada beberapa internal proses yang belum efektif dan efisien. 
4) Ada keahlian khusus yang masih belum dimiliki setiap personil yaitu jiwa pemasaran.

5) Diperlukannya personil-personil yang handal.

2. Lingkungan eksternal

a. Peluang

1) Masih luasnya pasar yang berada didalam maupun diluar Sumatera Barat.

2) Pertumbuhan pasar sasaran yang terus meningkat di Pasaman Barat.

3) Ekspektasi stokeholder terhadap organisasi yang tinggi.

4) Mahalnya dana institusi perbankan atau pembiayaan para pesaing.

5) Bentuk dan bidang investasi sangat luas dan beragam.

6) Banyaknya pasar potensial untuk beberapa tahun kedepan yang belum dijamah pesaing di Pasaman Barat.

7) Kebutuhan dan keinginan konsumen yang beragam.

8) Perekonomian masyarakat mulai meningkat di Pasaman Barat.

9) Keberadaan kantor Bank Pembangunan Daerah Sumatera Barat Cabang Simpang Empat yang tidak jauh dari pasar Simpang Empat.

b. Ancaman

1) Bermunculannya pesaing baru baik lembaga keuangan bank maupun non bank.

2) Adanya perubahan kebutuhan dan keinginan konsumen.

3) Masih ada sebagian masyarakat yang belum mengerti dengan peranan bank.

4) Makin berkembangnya teknologi dalam bidang pelayanan perbankan.

5) Anggapan masyarakat bahwa bank mempersulit proses pemberian kredit

6) Pelanggan sensitif terhadap kebijakan harga.

Berdasarkan kekuatan, kelemahan, peluang dan ancaman yang diperoleh melalui penelitian lingkungan internal dan eksternal, dapat formulasikan alternatif-alternati strategi yang dapat diambil oleh Bank Pembangunan Daerah Sumatera Barat Cabang Simpang Empat.Perumusan strategi ini dilakukan dengan menggunakan Matrik SWOT, dapat dilihat pada matrik dibawah ini.

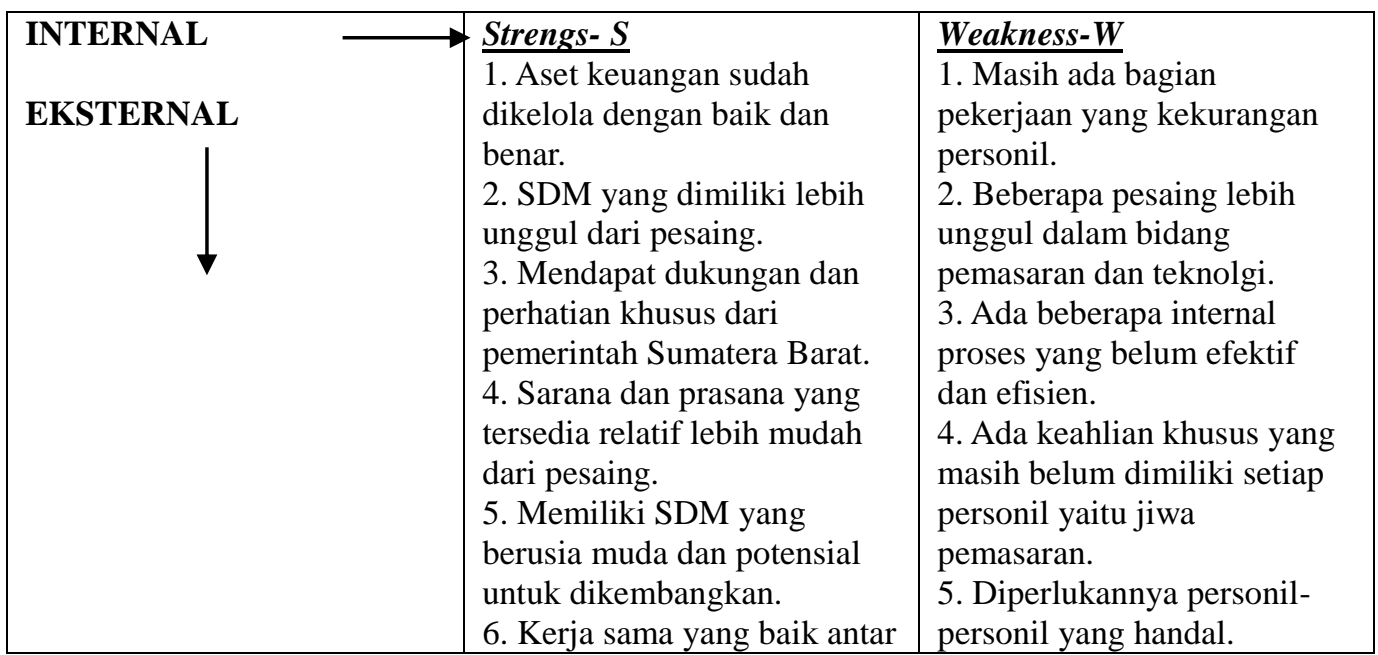




\begin{tabular}{|c|c|c|}
\hline & $\begin{array}{l}\text { personil. } \\
\text { 7. Image Bank Pembangunan } \\
\text { Daerah Sumatera Barat (Bank } \\
\text { Nagari) dimata masyarakat } \\
\text { luas sangat baik. } \\
\text { 8. Produk atau jasa yang di } \\
\text { tawarkan Bank Pembangunan } \\
\text { Daerah Sumatera Barat } \\
\text { bervariasi dan diminati oleh } \\
\text { masyarakat. } \\
\text { 9. Undian hadiah yang } \\
\text { dilakukan Bank } \\
\text { Pembangunan Daerah } \\
\text { Sumatera Barat merupakan } \\
\text { apresiasi terhadap pelanggan. } \\
\text { 10. Akses atas regulasi dan } \\
\text { informasi yang besar. } \\
\text { 11. Tabungan Sikoci } \\
\text { merupakan produk yang } \\
\text { paling diminati oleh } \\
\text { masyarakat. } \\
\text { 12. Jaringan kantor cabang } \\
\text { Bank Pembangunan Daerah } \\
\text { Sumatera Barat Cabang } \\
\text { Simpang Empat cukup } \\
\text { potensial dalam penyaluran } \\
\text { kredit. } \\
\text { 13. Telah memiliki standar } \\
\text { dan prosedur dalam } \\
\text { pemberian KUR. }\end{array}$ & \\
\hline $\begin{array}{l}\text { Opportunities- } \boldsymbol{O} \\
\text { 1. Masih luasnya pasar yang } \\
\text { berada didalam maupun } \\
\text { diluar Sumatera Barat. } \\
\text { 2. Pertumbuhan pasar sasaran } \\
\text { yang terus meningkat di } \\
\text { Pasaman Barat. } \\
\text { 3. Ekspektasi stokeholder } \\
\text { terhadap organisasi yang } \\
\text { tinggi. } \\
\text { 4. Mahalnya dana institusi } \\
\text { perbankan atau pembiayaan } \\
\text { para pesaing. } \\
\text { 5. Bentuk dan bidang } \\
\text { investasi sangat luas dan } \\
\text { beragam. } \\
\text { 6. Banyaknya pasar potensial } \\
\text { untuk beberapa tahun } \\
\text { kedepan yang belum dijamah } \\
\end{array}$ & $\begin{array}{l}\text { Strategi SO } \\
\text { 1. Memanfaatkan pangsa } \\
\text { pasar untuk mengetahui } \\
\text { kebutuhan masyarakat akan } \\
\text { layanan perbankan } \\
\text { 2. Memanfaatkan SDM yang } \\
\text { berkualitas untuk cepat } \\
\text { tanggap dalam melakukan } \\
\text { identifikasi pasar dan dalam } \\
\text { pemberian pelayanan } \\
\text { terhadap nasabah } \\
\text { 3. Memberikan suku bunga } \\
\text { yang menarik sesuai dengan } \\
\text { perkembangan ekonomi dan } \\
\text { inflasi } \\
\text { 4. Bank harus lebih agresif } \\
\text { dan meningkatkan } \\
\text { kerjasamanya dengan pihak } \\
\text { group atau aliansi }\end{array}$ & $\begin{array}{l}\text { Strategi WO } \\
\text { 1. Meningkatkan teknologi } \\
\text { dengan memanfaatkan } \\
\text { perkembangan teknologi } \\
\text { 2. Melakukan promosi gencar } \\
\text { agar mencakup pasar yang } \\
\text { besar dengan memanfaatkan } \\
\text { perkembangan teknologi } \\
\text { yaitu memanfaatkan } \\
\text { perkembangan teknologi } \\
\text { informasi didalam kegiatan } \\
\text { promosi. } \\
\text { 3. Menciptakan produk baru } \\
\text { untuk mengikuti selera pasar. } \\
\text { 4. Menambah fasilitas (ATM } \\
\text { dan Internet Banking) agar } \\
\text { mampu melayani pasar dan } \\
\text { mengikuti perubahan gaya } \\
\text { hidup masyarakat }\end{array}$ \\
\hline
\end{tabular}




\section{pesaing di Pasaman Barat.}

7. Kebutuhan dan keinginan

konsumen yang beragam.

8. Perekonomian masyarakat

mulai meningkat di Pasaman

Barat.

9. Keberadaan kantor Bank

Pembangunan Daerah

Sumatera Barat Cabang

Simpang Empat yang tidak

jauh dari pasar Simpang

Empat.

\section{Threats-T}

1. Bermunculannya pesaing baru baik lembaga keuangan bank maupun non bank.

2. Adanya perubahan kebutuhan dan keinginan konsumen.

3. Masih ada sebagian masyarakat yang belum mengerti dengan peranan bank.

4. Makin berkembangnya teknologi dalam bidang pelayanan perbankan.

5. Anggapan masyarakat bahwa bank mempersulit proses pemberian kredit 6. Pelanggan sensitif terhadap kebijakan harga.
5. Membuat media promosi tentang keuntungan dari produk KUR

6. Menjaga hubungan baik antara nasabah dengan petugas
5. Meningkatkan penjualan produk baik dari segi tabungan maupun kredit melalui peningkatan penjualan serta perluasan pasar sasaran

6. Meningkatkan pelatihan karyawan dan tenaga marketing agar mampu mencakup pasar yang besar

\section{Strategi ST}

1. Memanfaatkan SDM yang berkualitas untuk dapat memberikan service excellent bagi nasabah

2. Memberikan suku bunga yang kompetitif bagi nasabah baik dari segi simpanan maupun dari segi kredit 3. Pemanfaatan dan pengalokasian modal dengan tepat yang digunakan untuk pengembangan teknologi seoptimal mungkin 4. Memberikan informasi yang benar mengenai produk kredit usaha rakyat (KUR)

Bank Pembangunan Daerah Sumatera Barat dan melakukan persamaan persepsi kepada nasabah mengenai produk KUR tersebut agar masyarakat menghilangkan anggapan bahwa bank mempersulit proses pemberian kredit kepada masyrakat.

\section{Strategi WT}

1. Meningkatkan teknologi informasi agar mampu mengantisipasi persaingan dengan bank-bank lain 2. Melakukan kegiatan promosi yang intensif dan agresif untuk menghadapi bank-bank pesaing, pendatang baru maupun produk-produk substitusi 3. Menambah fasilitas (ATM dan Internet Banking) dan membuat inovasi produk agar terciptanya loyalitas nasabah 4. Memberikan pelayanan prima dengan birokrasi yang tidak berbelit-belit

\section{Strategi S-O (Strenght-Opportunity)}

Strategi S-O adalah strategi yang menggunakan kekuatan yang dimiliki oleh perusahaan untuk memanfaatkan peluang-peluang yang ada. Pilihan strategi yang digunakan oleh Bank Pembangunan Daerah Sumatera Barat Cabang Simpang Empat adalah :

a) Memanfaatkan pangsa pasar untuk mengetahui kebutuhan masyarakat akan layanan perbankan. Bank Pembangunan Daerah Sumatera Barat Cabang Simpang Empat memiliki 
pangsa pasar yang jelas yaitu para pelaku agrobisnis terutama perkebunan sawit, masyarakat pedesaan dan semua yang berada di wilayah layanan Bank Pembangunan Daerah Sumatera Barat Cabang Simpang Empat. Dengan target pasar yang lebih jelas tersebut bank lebih mudah untuk meneliti produk-produk yang sesuai dengan kebutuhan masyarakat.

b) Memanfaatkan SDM yang berkualitas untuk cepat tanggap dalam melakukan identifikasi pasar dan dalam pemberian pelayanan terhadap nasabah. Bank Pembangunan Daerah Sumatera Barat Cabang Simpang Empat memiliki sumber daya manusia yang berkualitas, karena semua karyawan yang bekerja telah memiliki keahlian sebelumnya. Oleh karena itu, Bank Pembangunan Daerah Sumatera Barat Cabang Simpang Empat harus memanfaatkan kualitas dan kemampuan para karyawannya untuk bisa merespon peluang pasar yang ada di sekitar lingkungan bank dan menyuguhkan pelayanan yang profesional.

c) Memberikan suku bunga yang menarik sesuai dengan perkembangan ekonomi dan inflasi. Hal ini dapat menarik para calon nasabah baru untuk menggunakan produk-produk Bank Pembangunan Daerah Sumatera Barat Cabang Simpang Empat.

d) Bank harus lebih agresif dan meningkatkan kerjasamanya dengan pihak group atau aliansi seperti dengan pemerintah daerah dan lembaga-lembaga lain yang merupakan aliansi dari Bank Pembangunan Daerah Sumatera Barat Cabang Simpang Empat. Dengan semakin banyaknya transaksi keuangan dengan pihak Group atau aliansi tidak menutup kemungkinan mereka akan merekomendasikan Bank Pembangunan Daerah Sumatera Barat Cabang Simpang Empat dengan mitra bisnis yang lain.

e) Membuat media promosi tentang keuntungan dari produk KUR untuk meningkatkan perekonomian masyarakat di tempat yang strategis di Simpang Empat. Sebagian kalangan masyarakat masih belum terlalu mengenal pruduk KUR ini, maka promosi yang dilakukan Bank Pembangunan Daerah Sumatera Barat Cabang Simpang Empat diharapkan dapat menimbulkan minat atau keinginan dihati masyarakat untuk menggunakan produk KUR yang ditawarkan oleh Bank Pembangunan Daerah Sumatera Barat Cabang Simpang Empat.

f) Menjaga hubungan baik antara nasabah dengan petugas.

\section{Strategi S-T (Strenght-Threath)}

Strategi S-T adalah strategi dimana perusahaan dapat menggunakan kekuatan untuk mengurangi atau juga menghindari ancaman yang berasal dari lingkungan eksternal perusahaan. Strategi yang dapat diterapkan perusahaan adalah:

a) Memanfaatkan SDM yang berkualitas untuk dapat memberikan service excellent bagi nasabah. Karyawan Bank Pembangunan Daerah Sumatera Barat Cabang Simpang Empat memiliki kualitas baik dan berpengalaman dibidangnya sehingga tidak diragukan kemampuannya untuk memberikan service excellent bagi nasabah sehingga nasabah loyal dan nyaman menggunakan produk Bank Pembangunan Daerah Sumatera Barat Cabang Simpang Empat.

b) Memberikan suku bunga yang kompetitif bagi nasabah baik dari segi simpanan maupun dari segi kredit, hal tersebut dapat digunakan sebagai kekuatan perusahaan mengingat ancaman persaingan dari pendatang-pendatang baru. Suku bunga simpanan Bank Pembangunan Daerah Sumatera Barat Cabang Simpang Empat yang cukup bagus, setidaknya mampu bersaing dengan bank-bank baru juga dengan lembaga keuangan non bank. Dengan memiliki kekuatan tersebut diharapkan bank mampu bertahan ditengah persaingan, dimana Indonesia merupakan pasar yang potensial untuk dimasuki oleh pesaing-pesaing baru dalam bidang perbankan. 
c) Pemanfaatan dan pengalokasian modal dengan tepat yang digunakan untuk pengembangan teknologi seoptimal mungkin. Bank Nagari Cabang Simpang Empat harus selalu mengikuti perkembangan teknologi terutama dalam bidang peningkatan pelayanan perbankan, hal tersebut akan dapat menghindari atau meminimalkan ancaman. Karena masyarakat lebih menyukai sesuatu yang dapat membuat urusan mereka lebih cepat dan mudah.

d) Memberikan informasi yang benar mengenai produk kredit usaha rakyat (KUR) Bank Pembangunan Daerah Sumatera Barat dan melakukan persamaan persepsi kepada nasabah mengenai produk KUR tersebut agar masyarakat menghilangkan anggapan bahwa bank mempersulit proses pemberian kredit kepada masyrakat.

\section{Strategi W-O (Weakness-Opportunity)}

Strategi W-O adalah strategi dimana perusahaan dapat mengatasi dan memperkecil kelemahan-kelemahan yang dimiliki oleh Bank Pembangunan Daerah Sumatera Barat Cabang Simpan Empat dengan memanfaatkan peluang-peluang yang ada. Strategi yang dapat dihasilkan adalah :

a) Meningkatkan teknologi dengan memanfaatkan perkembangan teknologi. Bank Pembangunan Daerah Sumatera Barat Cabang Simpang Empat harus mengikuti perkembangan teknologi agar tidak ketinggalan zaman. Bila bank tidak mengantisipasinya dari dini mungkin nasabah akan pindah ke Bank pesaing yang menggunakan teknologi canggih dan hal tersebut merupakan dampak yang merugikan bagi Bank Pembangunan Daerah Sumatera Barat Cabang Simpang Empat.

b) Bank Pembangunan Daerah Sumatera Barat Cabang Simpang Empat harus melakukan promosi gencar agar mencakup pasar yang besar dengan memanfaatkan perkembangan teknologi yaitu memanfaatkan perkembangan teknologi informasi didalam kegiatan promosi. Penggunaan teknologi dalam kegiatan promosi bisa melalui media-media promosi seperti radio-radio lokal di Pasaman Barat, melalui internet dan lain-lain sebagainya.

c) Menciptakan produk baru untuk mengikuti selera pasar.

d) Menambah fasilitas (ATM dan Internet Banking) agar mampu melayani pasar dan mengikuti perubahan gaya hidup masyarakat. Bank harus memberikan fasilitas yang memudahkan nasabah untuk bertransaksi. Dengan adanya kemudahan-kemudahan yang kita berikan kepada nasabah tentu akan dapat meningkatkan loyalitas mereka terhadap Bank Pembangunan Daerah Sumatera Barat Cabang Simpang Empat.

e) Meningkatkan penjualan produk baik dari segi tabungan maupun kredit melalui peningkatan penjualan serta perluasan pasar sasaran. Meningkatkan penjualan dapat dilakukan dengan cara memberikan penyuluhan-penyuluhan di daerah pedesaan yang masyarakatnya menghasilkan usaha pertanian atau perkebunan serta mengajak pemerintah setempat untuk bekerjasama membangun perekonomian desa. Presentasi yang diberikan menggunakan alat bantu seperti laptop, proyektor dan microphone untuk membantu mempresentasikan perusahaan. Tampilan dan isi presentasi harus menarik bahkan diberikan contoh video untuk bisa menarik minat masyarakat.

f) Meningkatkan pelatihan karyawan dan tenaga marketing agar mampu mencakup pasar yang besar. Bank harus terus memberikan pelatihan atau training yang continueagar mampu mengasah dan meningkatkan kualitas karyawannya. Serta menambah tenaga pemasar yang selama ini sangat kurang kuantitasnya. Padahal pasar yang dituju sangat luas, agar lebih semangat karyawan dapat diberikan fee atas peningkatan penjualan produk-produk Bank Pembangunan Daerah Sumatera Barat Cabang Simpang Empat. 


\section{Strategi W-T (Weakness-Threath)}

Strategi W-T merupakan taktik yang digunakan untuk bertahan dengan cara meminimalkan atau mengurangi kelemahan dan menghindari ancaman. Strategi yang dapat digunakan oleh Bank Pembangunan Daerah Sumatera Barat Cabang Simpang Empat adalah :

a) Meningkatkan teknologi informasi agar mampu mengantisipasi persaingan dengan bankbank lain. Perkembangan teknologi informasi yang dapat memberikan informasi seluasluasnya dapat dimanfaatkan untuk memunculkan ide kreatif dari pihak manajemen agar mampu bersaing dengan bank-bank lain.

b) Melakukan kegiatan promosi yang intensif dan agresif untuk menghadapi bank-bank pesaing, pendatang baru maupun produk-produk substitusi. Semakin banyaknya pesaingpesaing yang bermunculan di Pasaman Barat membuat Bank Pembangunan Daerah Sumatera Barat Cabang Simpang Empat harus melakukan promosi yang intensif agar produk lebih dikenal oleh masyarakat. Promosi dapat dilakukan dengan iklan di TV nasional tidak hanya TV lokal saja, Radio, Majalah, Koran. Selain itu, bank juga memberikan hadiah langsung atau bonus lainnya setiap pembukaan rekening baru atau pada periode-periode tertentu. Hal ini diharapkan agar Bank Pembangunan Daerah Sumatera Barat Cabang Simpang Empat mampu menghadapi persaingan yang semakin ketat dan tajam.

c) Menambah fasilitas (ATM dan Internet Banking) dan membuat inovasi produk agar terciptanya loyalitas nasabah. Bank yang unik dari yang lain akan membuat masyarakat yang belum menjadi nasabah memiliki rasa keinginan untuk mencoba dan menggunakan produk Bank Pembangunan Daerah Sumatera Barat Cabang Simpang Empat sementara yang sudah menjadi nasabah sebelumnya akan menjadi nasabah setia dan selalu menggunakan produk Bank tersebut.

d) Memberikan pelayanan prima dengan birokrasi yang tidak berbelit-belit. Dan selalu melakukan evaluasi terhadap pelaksanaan pemberian KUR Bank sesama pelaksana KUR dan kemudian dibandingkan dengan di Bank Pembangunan Daerah Sumatera Barat Cabang Simpang Empat.

\section{KESIMPULAN}

Hasil dari analisis lingkungan internal Bank Pembangunan Daerah Sumatera Barat Cabang Simpang Empat menunjukkan bahwa faktor internal yang menjadi kekuatan bank ini adalah pangsa pasar yang jelas, Bank Pembangunan Daerah Sumatera Barat juga sudah hampir memasuki skala nasional yaitu terbukti dengan adanya memiliki cabang di Pekan Baru, Jakarta dan Bandung yang dapat menimbulkan kebanggaan tersendiri bagi nasabah-nasabah Bank Pembangunan Daerah Sumatera Barat dimanpun mereka berada. Memiliki standar SDM yang berkualitas dan mampu bersaing, lokasi kantor yang strategis yaitu terletak di pusat ibu kota Pasaman Barat yaitu Simpang Empat, Bank Pembangunan Daerah Sumatera Barat Cabang Simpang Empat memiliki hubungan yang sangat dekat dengan pemerintahan daerah Pasaman Barat dan suku bunga tabungan dan suku bunga kredit yang ditawarkan lebih kompetitif. Sedangkan faktor-faktor internal yang menjadi kelemahan dari Bank Pembangunan Daerah Sumatera Barat Cabang Simpang Empat adalah teknologi yang digunakan masih standar, promosi yang dilakukan kurang maksimal, kurangnya fasilitas seperti ATM, kemampuan mengakses pasar terbatas, masih memerlukan personil-personil yang handal.

Hasil analisis lingkungan eksternal Bank Pembangunan Daerah Sumatera Barat Cabang Simpang Empat menunjukkan bahwa faktor-faktor eksternal yang menjadi peluang Bank Pembangunan Daerah Sumatera Barat Cabang Simpang Empat diantaranya adalah pasar yang 
masih luas dan besar, pertumbuhan pasar yang meningkat, perkembangan teknologi yang bisa dimanfaatkan untuk meningkatkan pelayanan terhadap nasabah, perubahan gaya hidup masyarakat, kebutuhan masyarakat yang beragam akan jasa-jasa perbankan dan pertumbuhan perekonomian masyarakat yang semakin meningkat. Sedangkan faktor-faktor eksternal yang menjadi ancaman bagi Bank Pembangunan Daerah Sumatera Barat Cabang Simpang Empat adalah ancaman pendatang baru baik dari lembaga keuangan bank maupun non bank, ancaman produk substitusi, adanya perubahan kebutuhan dan keinginan konsumen, perkembangan teknologi baru dalam bidang pelayanan perbankan, nasabah yang sensitif terhadap kebijakan harga, intervensi pemerintah melalui peraturan-peraturan dan bank-bank pesaing telah mengembangkan internet banking.

Melalui metode matrik SWOT maka telah diperoleh alternatif strategi-strategi yang dapat digunakan oleh BankPembangunan Daerah Sumatera Barat Cabang Simpang Empat untuk memanfaatkan peluang semaksimal mungkin dengan kekuatan-kekuatan yang dimiliki dan meminimalkan kelemahan serta ancaman agar Bank Pembangunan Daerah Sumatera Barat Cabang Simpang Empat mampu bersaing dan mampu mempertahankan eksistensinya dalam dunia bisnis perbankan. Beberapa diantaranya adalah :

a) Memanfaatkan pangsa pasar untuk mengetahui kebutuhan masyarakat akan layanan perbankan.

b) Memanfaatkan SDM yang berkualitas untuk cepat tanggap dalam melakukan identifikasi pasar dan dalam pemberian pelayanan terhadap nasabah.

c) Meningkatkan pelatihan karyawan dan tenaga marketing agar mampu mencakup pasar yang besar.

d) Memberikan suku bunga yang kompetitif bagi nasabah baik dari segi simpanan maupun dari segi kredit.

e) Memberikan pelayanan prima dengan birokrasi yang tidak berbelit-belit.

\section{Daftar Pustaka}

Endang, S.2007. Pemasaran Jasa. Bandung. CV Alfabeta

Kasmir. 2008. Pemasaran Bank. Jakarta.Kencana Prenada Media Group.

Kasmir. 2010. Manajemen Perbankan. Jakarta.PT Raja Grafindo Persada.

Kotler, P. 2000. Manajemen Pemasaran.Jakarta. Edisi Milenium. PT Prenhaliindo.

Prawitasari, Sri Y. Analisis SWOT Sebagai Dasar Perumusan Strategi Pemasaran Berdaya Saing (Studi Pada Dealer Honda Tunggul Sakti Di Semarang). Skripsi pada Program Sarjana Fakultas Ekonomi Universitas Diponegoro.

Rangkuti, F. 2005. Creating Effective Marketing Plan.Jakarta. PT Gramedia Pustaka Utama.

Rangkuti, F. 2009. Analisis SWOT Teknik Membedah Kasus Bisnis. Jakarta.PT Gramedia Pustaka Utama.

Rangkiti, F. 2011. SWOT Balanced Scorecard. PT Ikrar Mandiriabadi. Jakarta.

Septriana, L. 2011. Perumusan Strategi PT. Bank Agris.Bogor. Skripsi pada Departemen Manajemen, Fakultas Ekonomi dan Manajemen, Institut Pertanian Bogor. 
http://repository.ipb.ac.id/bitstream/handle/123456789/55813/BAB\%20III.\%20METODE\%20 PENELITIAN.pdf?sequence $=3$

http://jurnal-sdm.blogspot.com/2009/09/strategi-pemasaran-marketing-strategy.html http://library.binus.ac.id/eColls/eThesis/Bab2/2008-1-00229-MN\%20BAB\%202.pdf 